\title{
A Data Driven Analysis on Growth Factor Of COVID-19 and Its Correlation with Malaria Cases in India
}

\author{
A. P. Sharma, M. Gahlot, S. Deka, R. Kumar
}

\begin{abstract}
Introduction: COVID-19 coronavirus originated from Wuhan, China, had spread to more than 200 countries worldwide up to 3rd May 2020 [1]. The cumulative number of confirmed cases was 84393 in China and 3264847 totals in other countries [1]. All countries have taken measures to contain the outbreak of COVID-19. In India, till March about 15, 24, 266 passengers had been screened at the airports and 12,431 at the seaports [2]. Till 3rd May 2020 total 42533 confirmed COVID 2019 cases had been registered across India [2].
\end{abstract}

Aim: In this study, we analysed the data collected from different available official websites which reported the situation of COVID-19 infection in India to assess the growth of COVID-19 cases in India and to assess the relationship between Malaria cases and corresponding COVID-19 cases.

Method: A confirmed case of COVID-19 infection was defined as a case with a positive corona test report. Suspected cases were defined as a case with symptoms of COVID-19 infection but not confirmed. Growth factor of more than 1 shows the increasing number of cases, while growth factor between 0 to 1 shows a decline in the number of cases.

Results: The average growth factor from 21 January 2020 to 3rd May 2020 was 1.13 and before the first lockdown and after the first lockdown it was measured $1.10 \& 1.18$, respectively. On 5th March 2020, the growth factor was highest (Growth factor $=22$ ). Growth factor and number of new cases coming were significantly positive correlated $(r=0.39, p=0.035)$.

Conclusion: The future daily incidence size largely dependent on the change of new upcoming cases day by day. Our findings indicate that the social distancing and regulation measures are working, and COVID-19 spread in India can significantly lessen if these defensive actions continue to be implemented in a fitting way. The study also shows a positive correlation between malaria cases and COVID-19 cases.

Index Term-Observational Study, Growth factor, Retrospective.

\section{INTRODUCTION}

People often refer to the virus causing disease COVID-19 as "the coronavirus", Corona is a Latin form of "crown" due to its surface, which looks like a crown. In recent history SARS (2003) and MERS (2012) caused by coronaviruses.[1] In humans, 30\% common cold appears due to coronaviruses.[16] The outbreak of corona virus (COVID-19) was at first appeared in the city of Wuhan of Hubei province, China. On December 29, 2019, a conglomeration of same symptomatic cases of pneumonia appeared in Wuhan city, soon these cases were declared to

Published on August 27, 2020.

A. P. Sharma, Sekhmet Technologies Private Limited (THB), India.

(corresponding e-mail: ajendrapratap.stats@gmail.com)

M. Gahlot, Sekhmet Technologies Private Limited (THB), India. (e-mail: gahlotmohini@gmail.com)

S. Deka, Sekhmet Technologies Private Limited (THB), India. (e-mail: hisaurav2000@yahoo.co.in)

R. Kumar, Sekhmet Technologies Private Limited (THB), India. (e-mail: rohit@thb.co.in) be caused by novel corona virus which was eventually named SARS-CoV-2.2 or COVID-19. Today the virus is known as "Severe Acute Respiratory Syndrome Coronavirus 2" or SARS-CoV-2. These names were proposed by the World Health Organization and the International Committee on Taxonomy of Viruses [1]. Thailand was the first nation outside of China where the first instances of COVID-19 showed up on January 13, 2020, and then in Japan on January 16, 2020. The virus has now spread across the globe.

The most common indications of COVID-19 are fever, cough, and shortness of breath which may appear after exposure to the virus in 2 to 14 days [13]. These symptoms are usually mild and appear gradually. Some people become infected but do not develop any symptoms and do not feel unwell either. Most people (about 80\%) recover from the disease without needing special treatment. Around 1 out of every 5 people who gets COVID-19 becomes seriously ill and develops difficulty breathing. Older people, and those with underlying medical problems like high blood pressure, heart problems, or diabetes, are more likely to develop serious illness. People of any age who experience fever, cough, and difficulty breathing should seek for clinical attention immediately [2]. Coronaviruses are zoonotic, which means they are transmitted among animals and humans [1]. Coronavirus are a huge group of viruses with some causing less severe illness, like common cold, and other more severe ailment such as MERS and SARS. Some transmitted easily from human to human, while others do not [12]. This new coronavirus spreads human to human [13]. The disease spreads basically from individual to individual through beads release from the nose or mouth when an individual with COVID-19 hacks or wheezes. Individuals can get COVID-19 by contacting with infected person or by touching objects or surfaces where these droplets land on, and then touching their eyes, nose, or mouth. Therefore, it is important to stay more than 1 meter (3 feet) away from a person who is sick [2]. All countries have taken measures to contain the outbreak of COVID-19. In the absence of a vaccine, reducing contact rates in population has emerged as the most widely adopted strategy for its mitigation and control [18]. The suppression of social contact in workplaces, schools and other public spheres is the target of such measures. India's population as on 1 March 2020 stood at 1,380,004,385 (623.7 million males and 586.4 million females) [11]. In India, till March about $15,24,266$ passengers had been screened at the airports and 12,431 at the seaports [2]. Passengers were further monitored daily under community surveillance through IDSP (Integrated Disease Surveillance Programme) network. India had reported the first confirmed case of the coronavirus infection on 30 January 2020 in the state of Kerala. The affected had a travel history from Wuhan, 
China. Till 3rd May 2020 total 42533 confirmed cases of COVID-19 had been registered across India [2].

India and China, both are densely populated countries and share geographic borders which means that spread both to and from is extremely easy. Both countries have closeknitted communities which make social distancing a challenge. There, however, is a difference in the population distribution (Figure 1), India has a high younger population compared to China which gives India a slight advantage on the severity of COVID-19.

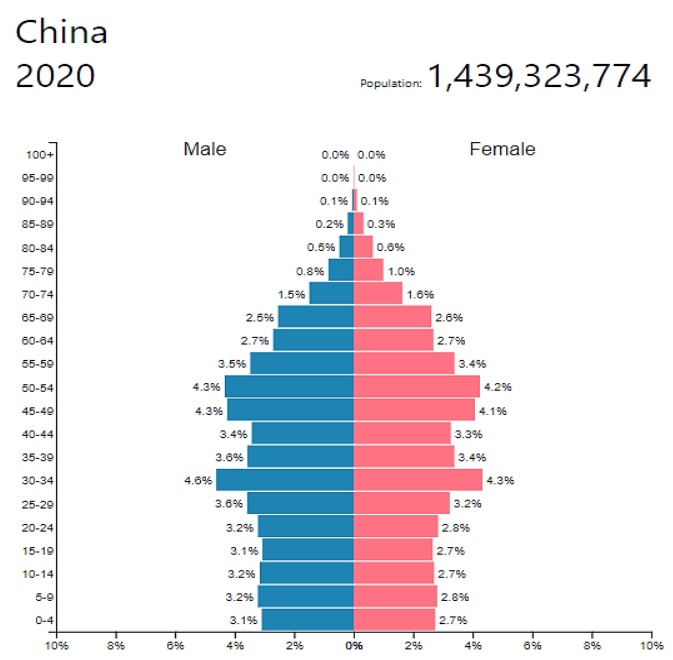

India

2020 Population: $1,380,004,385$

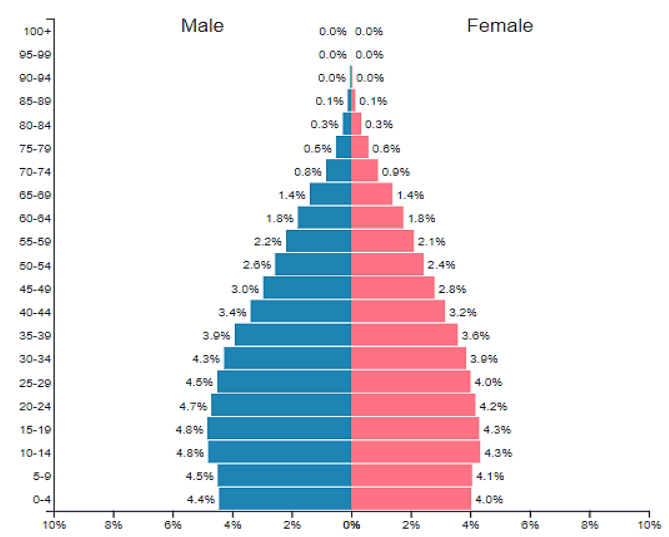

Fig. 1. Population pyramids by age and gender of India and China.

TABLE 1: Population Density TABle Of The Countries With POPULATION AT PRESENT

\begin{tabular}{lcc}
\hline \multicolumn{1}{c}{ Country } & $\begin{array}{c}\text { Population density } \\
\text { (person/Km2) }\end{array}$ & Population (2020) \\
\hline India & 419.8 & 1380004385 \\
China & 6787 & 1439323774 \\
\hline
\end{tabular}

The COVID-19 outbreak is a remarkable global public health challenge. In order for the governments, organisations in the country and individuals to respond to it in an effective manner, it would be crucial that they have easy access to good clear data and a good understanding of what can and cannot be said based on the available data.
In this paper we present the analysis of COVID-19 in India and try to find correlation between numbers of COVID-19 with malaria cases in the state/UT data of India.

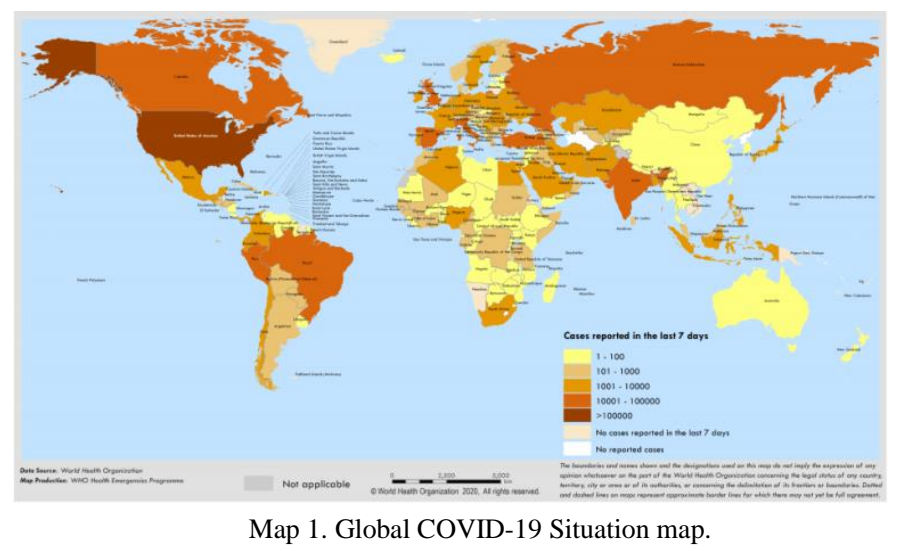

II. OBJECTIVE

\section{A. General Objective}

To Assess the growth factor of COVID-19 in India.

\section{B. Specific Objective}

Calculate the growth factor of COVID-19 in India.

Assess the relationship between Malaria cases and corresponding COVID-19 cases.

\section{METHODOLOGY}

Confirmed case of COVID-19 infection was defined as cases with a positive result. Suspected cases were defined as a case with symptoms of COVID-19 infection but not confirmed. Data source, all the data were collected from the official website that reported the situation of COVID-19 infection in India [1], [2]. The growth factor has been defined as the factor by which a quantity multiplies itself over time. The formula used every day's new cases / new cases on the previous day. A growth factor above 1 indicates an increase, whereas one which remains between 0 and 1 is a sign of decline, with the quantity eventually becoming zero, whereas a growth factor constantly above 1 could signal exponential growth. The growth rate we defined as percentage growth in cases. The formula for percentage growth change used (Today's Cases-Previous day cases)/Previous day cases) $* 100$ and for percentage growth rate used growth change $(\%)$ /duration. For mortality rate per 1000 , we used (number of deaths in duration/number of cases) $* 1000$.

\section{A. Study design}

Observational Study, Retrospective.

\section{B. Study Area}

India.

\section{Duration}

All the conformed COVID-19 cases from 21 January 2020 to 03 May 2020. 


\section{Data Collection}

Data collected from all the published evidence by the Government of India, the World Health Organisation, and the European Centre for Disease Prevention and Control from the official website related to COVID-19.

\section{E. Statistical Analysis}

All outcomes were presented using descriptive statistics. Continuous data were expressed as mean and SD. Categorical data as numbers and percentages. The comparison of mean differences of data was analysed by Mann-Whitney U-test / T-test and categorical variables by Chi-square test.

To estimate the relationships between a dependent variable and one or more independent variables, we used regression analysis, and to see the linear relationship between variables, we used Pearson's correlation coefficient to assess the linear relationship. P-Value equal to or less than 0.05 was considered as statistically significant.

All statistical analyses were performed using R-statistical tool version 3.5.3 and Microsoft excel.

\section{RESULTS}

Based on the published evidence we have performed a data-driven analysis primarily on the Indian population as follows:

\section{A. Spreading \& Growth}

India is the second-largest country in terms of population [19]. In India, the first case of COVID-19 appeared on 30th February 2020 [2]. Till 3rd May 2020, the global situation report indicates $1.91 \%$ of global cases reported from southeast Asia, and least number of cases appeared in Africa $(0.87 \%)$ while the European region had the highest number of cases (45.34\%) globally. Till 6th April 2020 total 40023 cases appeared in India [2] and the average growth factor of India was 1.13 since it was greater than 1 which indicates that COVID-19 cases in India are increasing.

TABLE 2. SPREADING OF CORONAVIRUS AROUND THE GLOBE AND IN INDIA TABLE 2A: GLOBAL SPREAD OF CORONA VIRUS

\begin{tabular}{lcccc}
\hline $\begin{array}{c}\text { COVID-19 Situa- } \\
\text { tion }\end{array}$ & Total Cases & $\begin{array}{c}\text { New } \\
\text { Cases }\end{array}$ & Deaths & $\begin{array}{c}\text { Cases } \\
(\%)\end{array}$ \\
\hline Globally & 3349786 & 82763 & 238628 & 100 \\
Western Pacific & 151444 & 1041 & 6229 & 4.52 \\
European & 1518895 & 27032 & 142667 & 45.34 \\
South-East Asia & 64047 & 3557 & 2375 & 1.91 \\
$\begin{array}{l}\text { Eastern Mediter- } \\
\text { ranean }\end{array}$ & 200609 & 5618 & 7871 & 5.98 \\
America & 1384641 & 44050 & 78409 & 41.33 \\
Africa & 29438 & 1465 & 1064 & 0.87 \\
\hline
\end{tabular}

TABLE 2B: CORONA CASES IN INDIA

\begin{tabular}{lcccc}
\hline \multicolumn{1}{c}{ Month } & Cases & Deaths & Case $(\%)$ & $\begin{array}{c}\text { Death } \\
(\%)\end{array}$ \\
\hline $\begin{array}{l}\text { January } \\
(21 / 01 / 2020)\end{array}$ & 1 & 0 & 0.02 & 0.00 \\
February & 2 & 0 & 0.05 & 0.00 \\
March & 1291 & 32 & 3.23 & 2.46 \\
April & 31799 & 1042 & 79.45 & 80.09 \\
May $(03 / 05 / 2020)$ & 6930 & 227 & 17.32 & 17.45 \\
\hline
\end{tabular}

\section{B. Growth Factor}

In the absence of a vaccine, social distancing had emerged as the most widely adopted strategy for the mitigation and control of COVID-19 spread, therefore Government of India took the decision to declare nationwide lockdown. On the $22^{\text {nd }}$ March 2020, first lockdown in India came into effect for 21 days. As the end of the first lockdown, period approached, on $14^{\text {th }}$ April 2020 the nationwide lockdown was extended till $3^{\text {rd }}$ May 2020. In the lockdown period, a drop in the average growth factor was observed as compared to the period before the lockdown (Table 3A). While the growth factor was greater than 1 depicting that the number of cases was growing, the speed of growth had slowed down, the same pattern was observed in average growth rate too.

TABLE 3A: OUTCOMES BEFORE AND AFTER LOCKDOWN

\begin{tabular}{lccc}
\hline \multicolumn{1}{c}{ Effect of } & $\begin{array}{c}\text { Before } \\
\text { lockdown } \\
\text { (21 Jan - 22 } \\
\text { March) }\end{array}$ & $\begin{array}{c}\text { Lockdown } \\
\text { phase 1 } \\
\text { (23 March - 14 } \\
\text { April) }\end{array}$ & $\begin{array}{c}\text { Lockdown } \\
\text { phase } 2 \\
\text { (15 April - 3 } \\
\text { May) }\end{array}$ \\
\hline $\begin{array}{l}\text { Number of } \\
\text { cases }\end{array}$ & $363^{*}$ & $10043^{*}$ & $29617^{*}$ \\
$\begin{array}{l}\text { Avg. Growth } \\
\text { Factor }\end{array}$ & 1.29 & 1.28 & 1.06 \\
$\begin{array}{l}\text { Mortality } \\
\text { Mortality Rate } \\
\text { (per 1000) }\end{array}$ & 4 & 335 & 962 \\
\hline
\end{tabular}

*Data were taken till $3^{\text {rd }}$ May 2020 from WHO, European Center for Disease Prevention and Control (ECDC), Ministry of health and family welfare, Govt. of India.

TABLE 3B: Distribution OF Average Growth FACTOR \& MORTALity

\begin{tabular}{lccc}
\multicolumn{1}{c}{ Month } & Cases & $\begin{array}{c}\text { Avg. Growth } \\
\text { Factor }\end{array}$ & $\begin{array}{c}\text { Mortality Rate } \\
\text { (per 1000) }\end{array}$ \\
\hline $\begin{array}{l}\text { January } \\
(21 / 01 / 2020)\end{array}$ & 1 & 0.00 & 0 \\
$\begin{array}{l}\text { February } \\
\text { March }\end{array}$ & 2 & 0.00 & 0 \\
April & 1291 & 2.51 & 24.78 \\
$\begin{array}{l}\text { May } \\
(03 / 05 / 2020)\end{array}$ & 31799 & 1.18 & 32.76 \\
\hline
\end{tabular}

According to the data published by the European Center for Disease Prevention and Control (ECDC) [20], the number of total confirmed deaths globally took 20 days to get multiplied. But, in India, it took 11 days to get doubled. The average growth factor of death was 1.07 (1st death on 13th March 2020), which was greater than 1 and indicated that the number of deaths was increasing.

TABLE 4: EFFECT OF LOCKDOWN ON GROWTH FACTOR

\begin{tabular}{lcc}
\hline \multicolumn{3}{c}{ TABLE 4: EFFECT OF LOCKDOWN ON GROWTH FACTOR } \\
\hline Growth factor in Lockdown & Mean & SD \\
\hline Before lockdown (21 Jan - 22 March) & 1.29 & 3.84 \\
Lockdown phase 1 (23 March - 14 April) & 1.28 & 0.76 \\
Lockdown phase 2 (15 April - 3 May) & 1.06 & 0.18 \\
\hline
\end{tabular}

* Growth factor calculated since the $1^{\text {st }}$ case registered in India. 
As shown in Table 4, the growth factor reduced after the lockdown. Comparing the growth factor before lockdown and after lockdown, was statistically significant ( $p<0.001)$, as our hypothesis was the growth factor between before lockdown and after lockdown was the same.

TABLE 5: GROWTH FACTOR COMPARISON BEFORE AND AFTER LOCK-

\begin{tabular}{cccccc}
\hline Comparison & Min & Max & Mean & SD & p-value \\
\hline $\begin{array}{c}\text { Before } \\
\text { lockdown } \\
\begin{array}{c}\text { After lock- } \\
\text { down }\end{array}\end{array}$ & 0.00 & 22.00 & 1.29 & 3.84 & \\
\hline
\end{tabular}

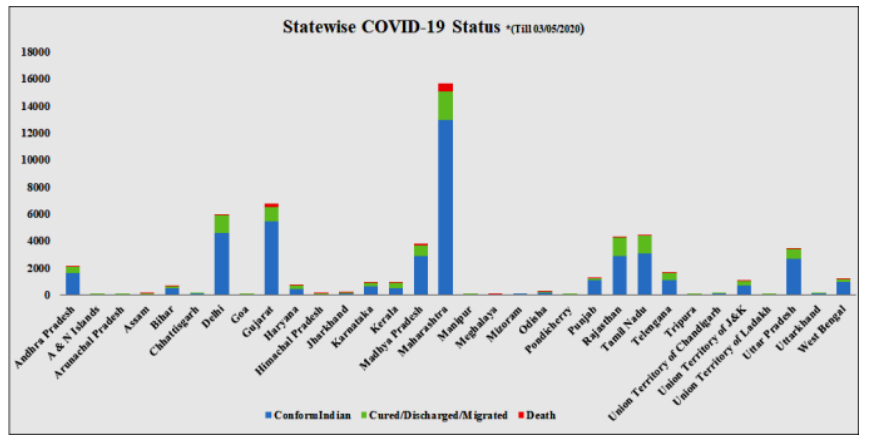

Graph 1. State-wise COVID-19 situation till $3^{\text {rd }}$ May 2020.

As from the above graph, we can see the highest number of cases as well as mortality, registered in Maharashtra followed by Gujarat.

\section{Comparison between Malaria cases \& COVID-19 cases in India:}

In 2018, an estimated 228 million cases of malaria occurred worldwide. Most malaria cases in 2018 were in the World Health Organization (WHO) African Region (213 million or 93\%), followed by the WHO South-East Asia Region with $3.4 \%$ of the cases and the WHO Eastern Mediterranean Region with $2.1 \%$. The WHO said that the number of deaths from malaria in Sub-Saharan Africa could be doubled this year, and COVID-19 may be the reason for increasing numbers [1]. Malaria is a public health problem in India. There is a similarity in symptoms of COVID-19 and malaria. "The early symptoms of COVID-19, including fever, myalgia, and fatigue, might be confused with malaria and lead to challenges in early clinical diagnosis. The peak season for malaria starts from May and a spike is seen after the monsoon, in July and August. Most malaria cases were reported from the eastern and central part of the country and from states which have the forest, hilly and tribal areas. These states include Odisha, Chhattisgarh, Jharkhand, Madhya Pradesh, Maharashtra, and some north-eastern states like Tripura, Meghalaya, and Mizoram [2]. The current situation with COVID-19, however, poses a threat to India's progress in reducing malaria cases.

TABLE 6A: COMPARISON OF MALARIA AND COVID-19 CASES

\begin{tabular}{ccccc}
\hline Malaria Vs. COVID & Mean & SD & r & P-value \\
\hline Log COVID & 2.26 & 1.14 & 0.39 & 0.035 \\
Log Malaria & 3.18 & 1.07 & & \\
\hline *r: Correlation coefficient & & &
\end{tabular}

TABLE 6B: COMPARISON OF MALARIA AND COVID-19 CASES With PERCENTAGE

\begin{tabular}{|c|c|c|c|c|}
\hline State/UT & $\begin{array}{c}\text { Malaria } \\
2019\end{array}$ & $\begin{array}{c}\text { Malaria } \\
\qquad \%)\end{array}$ & $\begin{array}{l}\text { COVID (3rd } \\
\text { May) }\end{array}$ & $\begin{array}{l}\text { COVID } \\
(\%)\end{array}$ \\
\hline A.N. Islands & 201 & 0.06 & 33 & 0.08 \\
\hline Andhra Pradesh & 3104 & 0.93 & 1583 & 3.72 \\
\hline $\begin{array}{l}\text { Arunachal Pra- } \\
\text { desh }\end{array}$ & 160 & 0.05 & 1 & 0.00 \\
\hline Assam & 1459 & 0.44 & 43 & 0.10 \\
\hline Bihar & 1441 & 0.43 & 503 & 1.18 \\
\hline Chandigarh & 5 & 0.00 & 94 & 0.22 \\
\hline Chhattisgarh & 60575 & 18.10 & 57 & 0.13 \\
\hline D \& N Haveli & 55 & 0.02 & 0 & 0.00 \\
\hline Daman \& Diu & 8 & 0.00 & 0 & 0.00 \\
\hline Delhi & 713 & 0.21 & 4549 & 10.70 \\
\hline Goa & 272 & 0.08 & 7 & 0.02 \\
\hline Gujarat & 13431 & 4.01 & 5428 & 12.76 \\
\hline Haryana & 967 & 0.29 & 442 & 1.04 \\
\hline Himachal Pradesh & 109 & 0.03 & 40 & 0.09 \\
\hline $\begin{array}{c}\text { Jammu \& Kash- } \\
\text { mir }\end{array}$ & 105 & 0.03 & 701 & 1.65 \\
\hline Jharkhand & 36552 & 10.92 & 115 & 0.27 \\
\hline Karnataka & 3333 & 1.00 & 614 & 1.44 \\
\hline Kerala & 655 & 0.20 & 500 & 1.18 \\
\hline Ladakh & 0 & 0.00 & 41 & 0.10 \\
\hline Lakshadweep & 11 & 0.00 & 0 & 0.00 \\
\hline Madhya Pradesh & 13757 & 4.11 & 2846 & 6.69 \\
\hline Maharashtra & 8866 & 2.65 & 12974 & 30.50 \\
\hline Manipur & 15 & 0.00 & 2 & 0.00 \\
\hline Meghalaya & 2615 & 0.78 & 12 & 0.03 \\
\hline Mizoram & 8277 & 2.47 & 1 & 0.00 \\
\hline Nagaland & 19 & 0.01 & 0 & 0.00 \\
\hline Orissa & 39557 & 11.82 & 162 & 0.38 \\
\hline Puducherry & 23 & 0.01 & 8 & 0.02 \\
\hline Punjab & 1143 & 0.34 & 1102 & 2.59 \\
\hline Rajasthan & 2060 & 0.62 & 2886 & 6.79 \\
\hline Sikkim & 6 & 0.00 & 0 & 0.00 \\
\hline Tamil Nadu & 2088 & 0.62 & 3023 & 7.11 \\
\hline Telangana & 1711 & 0.51 & 1082 & 2.54 \\
\hline Tripura & 12437 & 3.72 & 16 & 0.04 \\
\hline Uttar Pradesh & 92732 & 27.71 & 2645 & 6.22 \\
\hline Uttarakhand & 303 & 0.09 & 60 & 0.14 \\
\hline West Bengal & 25928 & 7.75 & 963 & 2.26 \\
\hline Total & 334693 & 100.00 & 42533 & 100.00 \\
\hline
\end{tabular}

Due to high dispersion in the numbers of COVID-19 and Malaria cases, we took log (numbers) of both variables as a result which shows that there is a significantly positive correlation between malaria cases and COVID-19 cases.

\section{CONCLUSION}

India was doing better in comparison to several other nations and the growth factor of Coronavirus cases had declined 40 percent in India. The doubling rate of positive cases was down to 6.2 days, compared to 3 before the 
nationwide lockdown that began on March 25. It had been witnessing an average growth factor at 1.2 since April 1 which stood at 2.1 between March 15 and March 13 . Nineteen States/UTs (Kerala, Uttarakhand, Haryana, Ladakh, Himachal, Chandigarh, Puducherry, Bihar, Odisha, Telangana, Tamil Nadu, Andhra Pradesh, Delhi, UP, Karnataka, J\&K, Punjab, Assam, Tripura) had shown a lower rate of increase of cases to some extent. This study indicates that the social distancing and regulation measures were working and capability of COVID-19 to spread in India can diminish if these defensive estimates will act in a fitting way.

\section{REFERENCES}

[1] World Health Organization. Coronavirus disease 2019 (COVID-19) Situation Report-19. $2020 \quad$ Available from: https://www.who.int/emergencies/diseases/novel-coronavirus2019/situation-reports.

[2] Ministry of Health and Family Welfare. The latest situation of new coronavirus pneumonia. Available from: https://pib.gov.in/PressReleseDetail.aspx? PRID=1604909 (Accessed on $4^{\text {th }}$ March 2020).

[3] Indian Council of Medical Research (ICMR). The latest situation of new coronavirus https://www.icmr.nic.in/content/special-issueindian-journal-medical-research-ijmr-coronavirus-india-covid-19,

[4] Huang CL, Wang YM, Li XS, R LL, Zhao JP, Hu Y, et al. Clinical features of patients infected with 2019 novel coronavirus in Wuhan, China[J]. Lancet, 2020.2 Available from: https://doi.org/10.1016/S0140-6736(20)30183-5 [Accessed 24 January 2020].

[5] Li Q, Guan XH, Wu P, Wang XY, Zhou L, Tong YQ, et al. Early Transmission Dynamics in Wuhan, China, of Novel CoronavirusInfected Pneumonia $[\mathrm{J}]$. N Engl J Med, 2020. Available from: https://www.nejm.org/doi/10.1056/NEJMoa2001316 [Accessed 29 January 2020].

[6] Nouvellet P, Cori A, Garske T, Blake I M, Dorigatti I, Hinsley W, et al. A simple approach to measure transmissibility and forecast incidence[J]. Epidemics, 2018, 22: 29-35.

[7] Zhao S, Lin QY, Ran JJ, Musa SS, Yang GP, Wang WM, et al. Preliminary estimation of the basic reproduction number of novel coronavirus (2019-nCoV) in China, from 2019 to 2020: A data-driven analysis in the early phase of the outbreak [J]. Int J Infect Dis, 2020. Available from: https://doi.org/10.1016/j.ijid.2020.01.050 [Accessed 30 January 2020].

[8] Wu JT, Leung K, Leung GM. Now casting and forecasting the potential domestic and international spread of the 2019-nCoV outbreak originating in Wuhan, China: a modelling study[J]. Lancet, 2020. Available from: https://doi.org/10.1016/S0140-6736 (20)302609 [Accessed 31 January 2020],

[9] Delamater P L, Street E J, Leslie T F, Yang Y T, Jacobsen K H. Complexity of the Basic Reproduction Number (R0)[J]. Emerg Infect Dis, 2019, 25(1): 1-4

[10] National Centre for Disease Control, Govt. Of India. Disease alert on COVID-19 Available from: https://ncdc.gov.in/index4.php?lang=1\&level=0\&linkid=127\&lid=43 2.

[11] National portal of India, Govt. Of India. Available from https://www.india.gov.in/india-glance/profile.

[12] Department of Health and Family Welfare, Govt. of Kerala, India. Available from http://dhs.kerala.gov.in/pdf2020/ncorona_26012020

[13] Centre for disease control and prevention, United State Department of Health \& Human Services. Available from https://www.cdc.gov/media/releases/2020/p0130-coronavirusspread.html.

[14] "Naming the coronavirus disease (COVID-19) and the virus that causes it". World Health Organization. The ICTV's page is here: International Committee on Taxonomy of Viruses (ICTV).

[15] Ren LL, Wang YM, Wu ZQ, et al. (2020) -Identification of a novel coronavirus causing severe pneumonia in human: a descriptive study [published online ahead of print, 2020 Feb 11]. Chin Med J (Engl). 2020;10.1097/CM9.0000000000000722. doi:10.1097/CM9.0000000000000722.

[16] Mesel-Lemoine M, Millet J, Vidalain PO, et al. (2012) - A human coronavirus responsible for the common cold massively kills dendritic cells but not monocytes. J Virol. 2012;86(14):7577-7587. doi:10.1128/JVI.00269-12

https://www.ncbi.nlm.nih.gov/pmc/articles/PMC3416289/.

[17] Smith RD (2006) - "Responding to global infectious disease outbreaks: lessons from SARS on the role of risk perception, communication and management". Social Science \& Medicine. 63 (12): 3113-23. doi: 10.1016/j.socscimed.2006.08.004.

[18] N. M. Ferguson et al., "Impact of non-pharmaceutical interventions (npis) to reduce covid-19 mortality and healthcare demand," London Imperial College COVID19 Response Team, March 16 (2020), $10.25561 / 77482$

[19] United Nations, Department of Economic and Social Affairs, Population Division. World Population Prospects,

[20] European Centre for Disease Prevention and Control https://www.ecdc.europa.eu/en/geographical-distribution-2019-ncovcases.

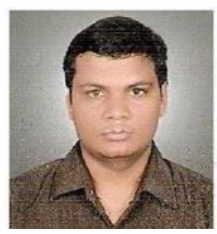

Mr. Ajendra Pratap Sharma is from Allahabad, Uttar Pradesh, India and was born on 30 0ctober 1988. He started his Bachelor of science in Mathematics \& Statistics from University of Allahabad in 2004. He then joined the same University for his Master of Sciences in Statistics in 2007. Currently he is the Biostatician to the Sekhmet Technologies Private Limited (THB), India a Contract Research Organization. He has held this post from 2020. Prior to joining THB. He has 9 years of experience in the field of STATISTICS.

He teamed up with his co-authors and have published many case reports in various indexed journals. He has a keen interest in research and has 6 publications to his credit in various journals. Some of his publications are

[1] Mehta, P., Parikh, P., Aggarwal, S., Batra, A., Patel, A., Kulkarni, P., Sahoo, R. K., Gupta, V. G., Bahl, C., Kumar, R., Pabbi, S., \& Sharma, A. P. (2020). Has India met this enemy before? From an eternal optimist's perspective: SARS-CoV-2. Indian Journal of Medical Sciences, 72(1), 8-12

[2] Jaggi, N., Chatterjee, N., Singh, V., Giri, S. K., Dwivedi, P., Panwar, R., \& Sharma, A. P. (2019). Carbapenem resistance in Escherichia coli and Klebsiella pneumoniae among Indian and international patients in North India. Acta microbiological et immunological Hungarian, 66(3), 367-376.

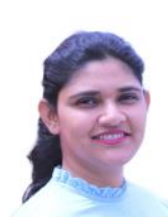

Mrs. Mohini Gahlot is from Delhi, India and born on 21 March 1990. She started her medical education in 2008 and graduated with Bachelor of Pharmacy from PGIMS Medical University in 2012. She then joined Abdul Kalam Technical University for PostGraduation (Master of Pharmacy) in clinical pharmacology in 2012. She had done a certification course in Understanding Clinical Research: Behind the Statistics from The Johns Hopkins University in 2019. Also done a Certification Course in Good Clinical Practices from The National Institute on Drug Abuse (NIDA) in 2019. She is a certified MedDRA Coder (Medical Dictionary for Regulatory Activities). Currently she is the Scientific Medical Writer attached to the Sekhmet Technologies Private Limited (THB), India a Contract Research Organization. She has held this post from 2019. Prior to joining THB, she was Clinical Research Associate at Chris O’Brien Cancer Hospital, Australia. She was Drug Safety specialist in Fortis Hospital, India from 2014 to 2017

She has interest in research and had presented some research article in national Society of Pharmaceutical Education and Research from year 2014-2017.

She has been awarded at SPER for participating in Evolution of Drug Discovery.

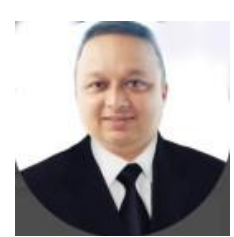

Dr. Saurav Deka is from Assam, India and born on 31 December 1980. He started his medical education in 1998 and graduated with M.B.B.S from Dibrugarh University, Assam in 2003. He then joined Assam Medical College \& Hospital for Post-Graduation (M.D.) in Clinical Pharmacology in 2005. He had done Certification for Advanced Cardiac Life Support (ACLS) at American Heart Association in 2015. Also done a certification course in Biostatistics \& Bioethics in Clinical Trials from The Johns Hopkins University in 2009.

Currently he is the Assistant vice President attached to the Sekhmet Technologies Private Limited (THB), India a Contract Research Organization. He has held this post from 2019. Prior to joining THB, he was Head 
Medical and Global Drug Development in Ajanta Pharma Ltd for 3 years. He was Physician, visiting lecture Qassim University in Dr Sulaiman Al Habib Hospital, Saudi Arabia from 2015 to 2017.

He teamed up with his co-authors and have published many case reports in various indexed journals. He has a keen interest in research and has 8 publications to his credit in various journals. Some of his publications are:

[1] DAS S, DEKA S, GOHAIN K. (2008). A Preclinical Study on The Gastric Ulcer Protective Activity of The World's Hottest Chilli, Capsicum Frutescenes, 2(4), 1024-1027.

[2] S Das, S Dutta, S Deka. A study of the anti-ulcer activity of the ethanolic extract of the leaves of Psidium guajava on experimental animal models. The Internet Journal of Pharmacology. 2008 Volume 7 Number 1.

He has been awarded by State Merit Scholarship at Assam Government. He has been awarded by NCC- B certificate at National Cadet Corps.

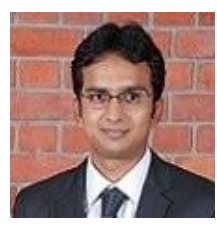

Mr. Rohit Kumar is from and born on 10 December 1981. He started his Bachelor of Technology in 2004 from Indian Institute of Technology, Kharagpur. He then joined Indian Institute of Management, Lucknow for Post-Graduation in Finance \& Economics in 2010. Currently he is the Co-Founder, CAO, and Data Analytics Expert of the Sekhmet Technologies Private Limited (THB), India a Contract Research Organization. He found this company in 2015. Prior to start his company, he was Manger and Analyst in American Express for 4years. His Publication is:

[1] Identification of aeroelastic quasi-steady effects through flex factor. Publication date Nov 2008 in Journal of Aerospace Sciences and Technologies.

He has been awarded with Certificate of Merit. He had represented THB as a panel member for the Confederation of Indian Industry (CII) NR Healthcare Summit 2020 and spoke on the evolution of patient life cycle, from the digitization of onboarding to service deliverables, and handling of patient information (data sensitivity and confidentiality). 